R.E. KALININ, I.A. SUCHKOV, A.S. PSHENNIKOV, A.A. KAMAEV, S.A. ISAKOV, A.N. RYABKOV

\title{
APPLICATION OF MAGNESIUM DRUGS AND THEIR INFLUENCE ON THE INDICATORS OF CONNECTIVE TISSUE DYSPLASIA IN PATIENTS WITH VARICOSE VEINS
}

\author{
Ryazan State Medical University \\ named after Academician I.P. Pavlov, Ryazan, \\ Russian Federation
}

Цель. Изучение влияния приема препаратов магния на концентрацию матриксных металлопротеиназ и ионов магния у пациентов с варикозной болезнью вен нижних конечностей.

Материал и методы. В исследование включено 124 пациента с варикозной болезнью вен нижних конечностей (ВБВНК) классов С2-С6, которых разделили на 4 группы. В І-й группе проводили оперативное лечение с последующим назначением стандартного консервативного лечения (32 человека); во II-й группе после операции в дополнение к консервативному лечению назначали препараты магния (32 человека); в III-й группе проводили консервативное лечение без операции (30 человек); в IV-й группе пациенты получали стандартное консервативное лечение и препараты магния (30 человек). V-ю контрольную группу составили 20 здоровых добровольцев, не страдающих варикозной болезнью. Пациентам II-й и IV-й групп назначали магния оротат 500 мг 2 табл. 3 раза в день в течение 3 мес. Содержание в сыворотке крови матриксной металлопротеиназы-1 (ММП-1), матриксной металлопротеиназы-9 (ММП-9), тканевого ингибитора матриксной металлопротеиназы-1 (ТИМП-1) определяли методом количественного твердофазного иммуноферментного анализа. Концентрацию ионов магния определяли колориметрическим методом.

Результаты. У пациентов с ВБВНК отмечался достоверно меньший уровень магния по сравнению с условно здоровыми добровольцами, не страдающими варикозной болезнью: $35,5 \%$ среди страдающих варикозной болезнью имели дефицит магния, в то время как всего $15 \%$ имели снижение данного показателя среди здоровых добровольцев. На фоне проводимой дополнительной терапии препаратами магния, отмечалось уменьшение количества пациентов с дефицитом магния в группах с ВБВНК, снижение концентрации ММП-9 и повышение активности ТИМП-1.

Заключение. Исследование подтвердило эффективность применения препаратов магния, которые обладают выраженным влиянием на процессы деградации коллагена и внеклеточного матрикса, снижают активность ММП-9, повышают концентрацию ТИМП-1, тем самым влияя на баланс ММП/ТИМП у пациентов с ВБВНК.

Ключевые слова: первичное варикозное расширение вен, фармакотерапия, магний, матриксные металлопротеиназы, дисплазия соединительной ткани

Objective. To study the effect of magnesium drugs on the concentration of matrix metalloproteinases and magnesium ions in patients with varicose veins of the lower extremities.

Methods. The study included 124 patients with varicose veins of the lower extremities, C2-C6, which were divided into 4 groups. In the $1^{\text {st }}$ group, surgical treatment followed with the administering the standard conservative treatment (32 patient); in the $2^{\text {nd }}$ group after the operation in addition to conservative treatment, magnesium drugs (32 patient) were prescribed; in the $3^{\text {rd }}$ group, conservative treatment without surgery (30 patient) was performed; in the $4^{\text {th }}$ group patients received standard conservative treatment and magnesium drugs (30 patient). The $5^{\text {th }}$ control group consisted of 20 healthy volunteers who did not suffer from varicose veins disease. Patients of groups 2 and 4 were given magnesium orotate $500 \mathrm{mg} 2$ tablets 3 times a day for 3 months. The content of serum matrix metalloproteinase-1 (MMP-1), matrix metalloproteinase-9 (MMP-9), tissue inhibitor of matrix metalloproteinase-1 (TIMP-1) was determined by quantitative solid-phase enzyme immunoassay. The magnesium ion concentration was determined by colorimetric method.

Results. In patients with varicose veins of lower extremities a significantly lower level of magnesium was registered compared to healthy volunteers not suffering from varicose veins: $35.5 \%$ of those with varicose veins had a magnesium deficiency, while only $15 \%$ had a decrease in this indicator among healthy volunteers. Against the background of additional therapy with magnesium drugs, there was a decrease in the number of patients with magnesium deficiency in groups with varicose veins of lower extremities, a decrease in MMP-9 concentration and an increase in TIMP-1 activity was also established.

Conclusions. This study has confirmed the efficacy of magnesium drugs which have a pronounced effect on collagen degradation processes and extracellular matrix, reduce the activity of MMP-9, increase the concentration of TIMP-1, thereby affecting the MMP/TIMP balance in patients with varicose veins of lower extremities. 


\begin{abstract}
Keywords: primary varicose veins, pharmacotherapy, magnesium, matrix metalloproteinase, connective tissue dysplasia

Novosti Khirurgii. 2018 Jan-Feb; Vol 26 (1): $51-59$

Application of Magnesium Drugs and Their Influence on the Indicators

of Connective Tissue Dysplasia in Patients with Varicose Veins

R.E. Kalinin, I.A. Suchkov, A.S. Pshennikov, A.A. Kamaev, S.A. Isakov, A.N. Ryabkov

Научная новизна статьи

Произведена комплексная биохимическая оценка маркеров дисплазии соединительной ткани (ионов магния, матриксных металлопротеиназ, тканевого ингибитора матриксных металлопротеиназ) у пациентов с варикозной болезнью нижних конечностей. Проведен анализ влияния препаратов магния в лечении данной патологии. Подтверждена целесообразность применения препаратов магния у пациентов с варикозной болезнью, в том числе и у перенесших флебэктомию, с позиции влияния их на уровень матриксных металлопротеиназ и их ингибиторов.
\end{abstract}

\title{
What this paper adds
}

A complex biochemical assessment of markers of connective tissue dysplasia (magnesium ions, matrix metalloproteinases, tissue inhibitor of matrix metalloproteinases) in patients with varicose veins has been performed. An analysis of the effect of magnesium drugs in the treatment of this pathology has been conducted. The expediency of using magnesium drugs in patients with varicose veins, including those who underwent phlebectomy, has been confirmed from the position of their influence on the level of matrix metalloproteinases and their inhibitors.

\section{Introduction}

Varicose veins of the lower extremities are one of the most common diseases of peripheral vessels $[1,2,3]$. According to leading Russian phlebologists, more than 35 million people suffer from chronic venous insufficiency (CVI), which develops against the background of varicose veins, $15 \%$ of them have complicated forms of the disease [4].

Despite the successes achieved in the treatment and diagnosis of patients with varicose veins, many unsolved problems still remain, both theoretical and practical. We have to state that still much remains unclear in etiology and pathogenesis of varicose veins, which, in fact, is represented by a certain set of risk factors, the priority and significance of which may be different [5].

Several years ago, the idea about the participation of special matrix enzymes - metalloproteinases in the development of varicose veins of the subcutaneous veins was stated for the first time. Metalloproteinases play an important role in the development of such physiological processes as morphogenesis, resorption, tissue remodeling, angiogenesis. The function of metalloproteinases consists in the degradation of various protein components of the intercellular matrix (collagen, elastin, fibronectin, glycosaminoglycan) and, in general, in maintaining its homeostasis. In the preservation of metalloproteinases in a latent form and preventing their excessive activation, tissue inhibitors of metalloproteinases play an important role. Among them, the tissue inhibitor metalloproteinases-1 (TIMP-1) regulates the activity of matrix metalloproteinase-1 (MMP-1) and matrix metalloproteinase-9 (MMP-9) in the body. For the normal course of the processes of the extracellular matrix reorganization, it is necessary to maintain an equilibrium between the activity of metalloproteinases and their inhibitors [6, 7].

Also, according to modern concepts, varicose veins are a group of hereditary diseases that are directly related to a violation of synthesis or degradation of fibrous connective tissue structures that occur in the embryonic and postnatal periods of life. Understanding the role of magnesium in maintaining the structure of connective tissue is inseparable from the molecular-cellular structure of connective tissue. Magnesium is a universal regulator of biochemical and physiological processes in the body: it participates in energy, plastic and electrolyte metabolism [8, 9]. Magnesium as a physiological factor in synthesis of collagen is of particular interest.

Experiments on animals confirm the effect of magnesium on the biological activity of MMP. In mice with artificially induced magnesium deficiency, there is a significant thinning of the aortic wall compared to control animals. The specific coloration of the two main types of fibers (collagen and elastin) has shown significant structural changes in both components. These changes correlated with an increase in the total activity of matrix metalloproteinases MMP-2 and MMP-9 [10].

The data given above suggest that the $\mathrm{Mg}^{2+}$ deficiency should probably lead to an increase in MMP activity, which begin to destroy the structural components of the extracellular matrix (ECM) (primarily collagen) at a higher rate, and also affect the tissue inhibitors of matrix metalloproteinases.

Objective. To study the effect of magnesium drugs on the concentration of matrix metalloproteinases and magnesium ions in patients with varicose veins of the lower extremities. 


\section{Methods}

The study included 124 patients with varicose veins, C2-C6, which were divided into 4 groups. In the 1st group, surgical treatment followed with the administering the standard conservative treatment (32 patient); in the $2^{\text {nd }}$ group after the operation in addition to conservative treatment, magnesium drugs ( 32 patient) were prescribed; in the 3 rd group, conservative treatment without surgery (30 patient) was performed; in the $4^{\text {th }}$ group patients received standard conservative treatment and magnesium drugs ( 30 patient). The $5^{\text {th }}$ control group consisted of 20 healthy volunteers who did not suffer from varicose veins. Patients of groups 2 and 4 were given magnesium orotate $500 \mathrm{mg} 2$ tablets 3 times a day for 3 months. The study was not of an intervention nature, the choice of the treatment option was determined by the attending physician, taking into account the capabilities and desires of a patient.

The study was approved by the ethical committee of the Ryazan State Medical University named after Academician I.P. Pavlov.

The groups were comparable by sex, age, concomitant diseases, clinical class and duration of the disease. The distribution of patients by group, sex and age is presented in Table 1.

The criterion for inclusion in the study of patients of groups I-IV was clinically and instrumentally verified varicose veins of the lower extremities, in the control group - the absence of varicose veins. Exclusion criteria were previous thrombophlebitis of the superficial veins of the lower limbs; deep vein thrombosis of the lower limbs; obliterating diseases of the aorta, peripheral artery disease of the pelvis and lower limbs; coronary artery disease, acute impairment of cerebral circulation in the anamnesis; diabetes; operations and manipulations on the superficial veins of the lower limbs; infectious-inflammatory diseases of soft tissues of the lower limbs. The study was approved by a local ethics committee and all patients signed the informed consent to participate in the study.

The samples of peripheral blood taken in the morning on an empty stomach were examined. The serum levels of MMP-9, MMP-1, and TIMP-1 were determined by quantitative solid-phase enzyme immunoassay method using enzyme immunoassay kit for quantitative in vitro detection of matrix metalloproteinases in serum, blood plasma and other biological fluids, as well as cell lysates and supernatant of cell cultures (AbFrontier human MMP-1 ELISA, China, Bender MedSystems human MMP-9 ELISA, USA; Bender MedSystems human TIMP-9 ELISA, USA).

The concentration of $\mathrm{Mg}^{2+}$ was determined by photocolorimetric method using the "MAGNIUMOLVEX" kit (Olvex-Diagnosticum, Russia). Blood sampling for determining the level of biochemical markers was carried out at the beginning of the study and subsequently 1, 3 and 6 months after the start of treatment in patients with conservative and operative groups with varicose veins.

\section{Statistics}

The determination of the mean values, the standard deviation and the error of the arithmetic mean was made. To compare the values in the groups, the Student's t-test was used. For the confidence level, the probability of a difference of $95 \%$ was accepted $(p<0.05)$. To compare independent groups by qualitative characteristics, the Pearson's chi-squared test $\chi^{2}$ was used.

\section{Results}

According to WHO recommendations, the normal content of magnesium in serum is:

The distribution of patients by group, sex and age

Table 1

\begin{tabular}{|c|c|c|c|c|c|c|}
\hline \multirow[t]{2}{*}{ Groups } & \multirow[t]{2}{*}{$\mathrm{N}$} & \multirow[t]{2}{*}{ Clinical case (CEAP) } & \multirow{2}{*}{$\begin{array}{l}\text { Age, years } \\
(\mathrm{M} \pm \sigma)\end{array}$} & \multirow{2}{*}{$\begin{array}{l}\text { Disease duration, } \\
\quad(\mathrm{M} \pm \sigma)\end{array}$} & \multicolumn{2}{|c|}{$\operatorname{Sex}($ abs. $/ \%)$} \\
\hline & & & & & Males & Females \\
\hline I. & 32 & $\begin{array}{l}\text { C2-C3 - } 18 \text { patient }(56.25 \%) \\
\text { C4 }-6 \text { patient }(18.75 \%) \\
\text { C5-C6 - 8 patient }(25 \%)\end{array}$ & $41.1 \pm 7.2$ & $10.1 \pm 3.2$ & $13(40.6 \%)$ & $19(59.4 \%)$ \\
\hline II. & 32 & $\begin{array}{c}\text { C2-C3 - } 18 \text { patient }(56.25 \%) \\
\text { C4 - } 6 \text { patient }(18.75 \%) \\
\text { C5-C6 - 8 patient }(25 \%)\end{array}$ & $45.2 \pm 9.3$ & $11.1 \pm 2.7$ & $14(43.8 \%)$ & $18(56.2 \%)$ \\
\hline III. & 30 & $\begin{array}{c}\mathrm{C} 2-\mathrm{C} 3-18 \text { patient }(60 \%) \\
\mathrm{C} 4-5 \text { patient }(16.7 \%) \\
\mathrm{C} 5-\mathrm{C} 6-7 \text { patient }(23.3 \%)\end{array}$ & $48.7 \pm 8.7$ & $7.6 \pm 1.5$ & $13(43.3 \%)$ & $17(56.7 \%)$ \\
\hline IV. & 30 & $\begin{array}{l}\mathrm{C} 2-\mathrm{C} 3-18 \text { patient }(60 \%) \\
\mathrm{C} 4-5 \text { patient }(16.7 \%) \\
\mathrm{C} 5-\mathrm{C} 6-7 \text { patient }(23.3 \%)\end{array}$ & $43.1 \pm 9.4$ & $7.2 \pm 4.3$ & $12(40 \%)$ & $18(60 \%)$ \\
\hline V. & 20 & - & $44.1 \pm 6.2$ & - & $8(40 \%)$ & $12(60 \%)$ \\
\hline
\end{tabular}




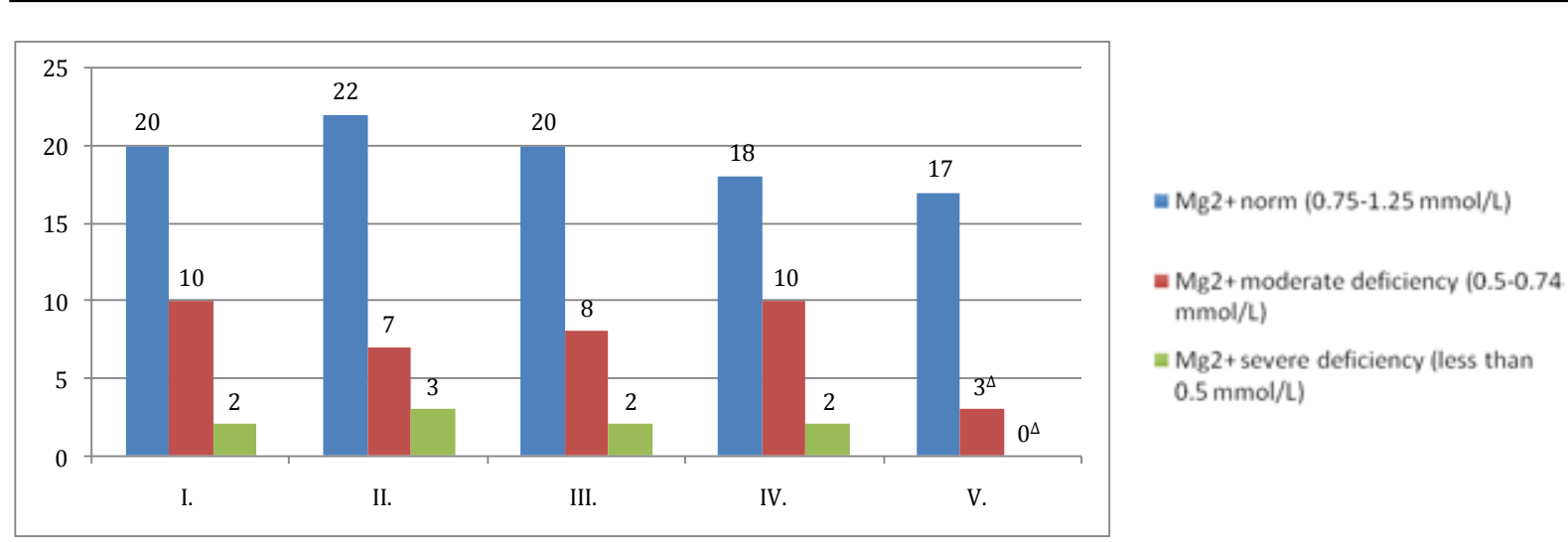

Fig. 1. Distribution of patients with magnesium deficiency in groups.

$\Delta$ - significant difference from groups of patients with varicose veins at the stage of screening $(p<0.05)$.

- from 0.74 to $1.15 \mathrm{mmol} / \mathrm{L}$ for children,

- from 0.75 to $1.26 \mathrm{mmol} / \mathrm{L}$ for adults,

- from 0.8 to $1.05 \mathrm{mmol} / \mathrm{L}$ for pregnant women.

At the same time, $0.5-0.74 \mathrm{mmol} / \mathrm{L}$ testifies to moderate magnesium deficiency in the body, and a level below $0.5 \mathrm{mmol} / \mathrm{L}$ - to a pronounced deficiency of magnesium ions.

Blood samples of patients with varicose veins and patients of the control group were taken as initial biochemical indices. The following results were obtained. In patients with varicose veins before the start of treatment in $64.5 \%$ of cases $(80$ people) normal values of $\mathrm{Mg}^{2+}$ were observed. In
35 people $(28.2 \%)$ there was a moderate decrease in magnesium concentration. And a pronounced deficit was observed in the remaining 9 patients (7.3\%). In the control group, only three people had a deficiency of magnesium (15\%) (Fig. 1).

Further, against the background of the therapy, a significant decrease in the number of patients with magnesium deficiency in the second and fourth groups after 1 month of therapy was registered $(p<0.05)$, and this indicator remained low throughout the study. While in the first and third groups throughout the study, the number of patients with magnesium deficiency remained at the initial level (Table 2).

\section{Dynamics of changes in the number of patients with magnesium deficiency}

Table 2

\begin{tabular}{|c|c|c|c|c|}
\hline \multirow[t]{2}{*}{ Groups } & \multicolumn{4}{|c|}{ Number of patients with magnesium deficiency $\left(\mathrm{Mg}^{2+}<0,75 \mathrm{mmol} / \mathrm{L}\right)$} \\
\hline & V0 & V1 (after 1 month) & V2 (after 3 months) & V3 (after 6 months) \\
\hline I. & $37.5 \%$ (12 people) & $34.4 \%$ (11 people) & $34.4 \%$ (11 people) & $34.4 \%$ (11 people) \\
\hline II. & $31.3 \%$ (10 people) & $9.4 \% *$ (3 people) & $3.1 \% *$ ( 1 person $)$ & $3.1 \% *$ ( 1 person $)$ \\
\hline III. & $33.3 \%$ (10 people) & $33.3 \%$ (10 people) & $33.3 \%$ (10 people) & $36.7 \%$ (11 people) \\
\hline IV. & $40 \%$ (12 people) & $10 \% *$ (3 people) & $0 \% *(0$ people $)$ & $3.3 \% *$ (1 person) \\
\hline $\mathrm{V}$. & $15 \%^{\Delta}$ (3 people) & - & - & - \\
\hline
\end{tabular}
veins at the stage of screening $(\mathrm{p}<0.05)$.

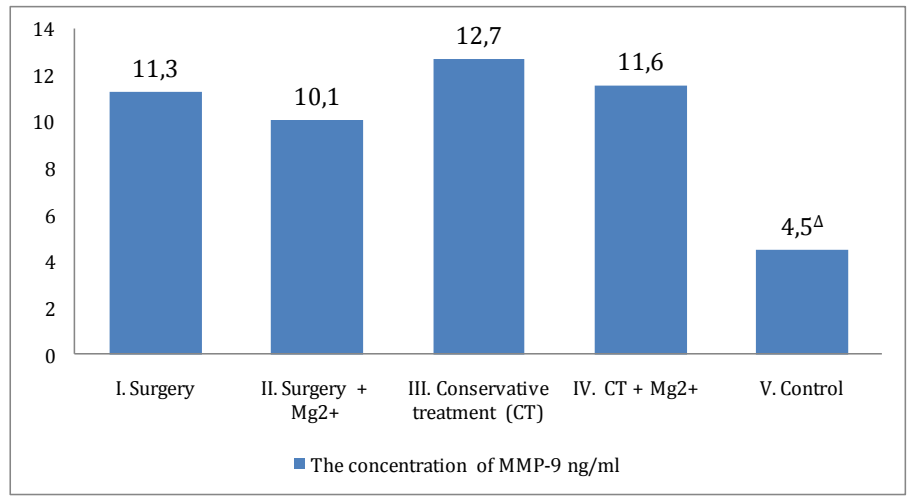

Fig. 2. The concentration of MMP-9 in patients with varicose veins and the control group at the stage of inclusion in the study.

$\Delta$ - significant difference from groups of patients with varicose veins at the stage of screening $(p<0.05)$. 
The concentration of MMP-9 in patients of different groups $(\mathrm{M} \pm \mathrm{m})$

\begin{tabular}{|c|c|c|c|c|}
\hline Groups & $\begin{array}{c}\mathrm{V} 0 \\
\mathrm{ng} / \mathrm{ml}\end{array}$ & $\begin{array}{c}\text { V1 (after } 1 \text { month) } \\
\mathrm{ng} / \mathrm{ml}\end{array}$ & $\begin{array}{c}\text { V2 (after } 3 \text { months) } \\
n \mathrm{ng} / \mathrm{ml}\end{array}$ & $\begin{array}{c}\mathrm{V} 3 \text { (after } 6 \text { months) } \\
\mathrm{ng} / \mathrm{ml}\end{array}$ \\
\hline I. & $11.3 \pm 1.7$ & $12.2 \pm 2.2^{* *}$ & $11.5 \pm 1.4^{* * *}$ & $11.2 \pm 1.9^{* * *}$ \\
\hline II. & $10.1 \pm 1.3$ & $6.2 \pm 0.8^{*}$ & $5.4 \pm 2.1^{*}$ & $5.5 \pm 2.1^{*}$ \\
\hline III. & $12.7 \pm 2.5$ & $12.2 \pm 1.3^{* *}$ & $11.7 \pm 2.2^{* * *}$ & $11.4 \pm 2.4^{* * *}$ \\
\hline IV. & $11.6 \pm 2.1$ & $8.7 \pm 1.1^{*}$ & $8.0 \pm 1.4^{*}$ & $7.6 \pm 0.9^{*}$ \\
\hline V. & $4.5 \pm 1.3$ & - & - & - \\
\hline
\end{tabular}

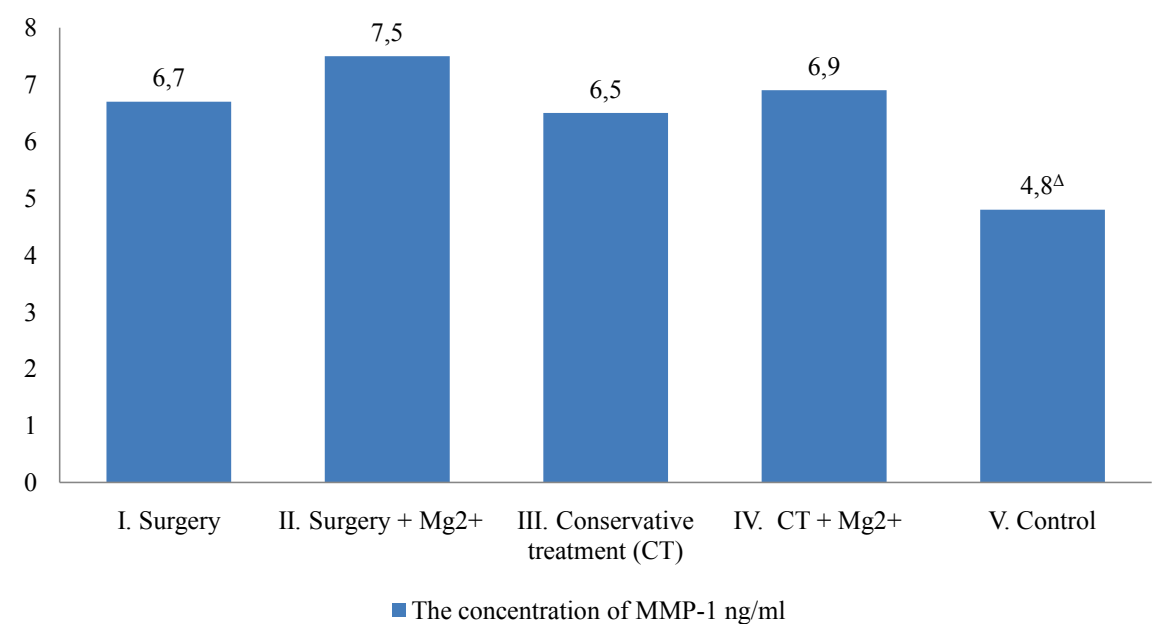

Fig. 3. The concentration of MMP-1 in patients with varicose veins and the control group at the stage of inclusion in the study.

$\Delta$ - significant difference from groups of patients with varicose veins at the stage of screening $(p<0.05)$.

In the control group, the concentration of MMP-9 was $4.5 \pm 1.32 \mathrm{ng} / \mathrm{ml}$. In groups of patients with varicose veins, a significantly lower MMP-9 level was found in comparison with the control group (11.3 $\pm 4.86 \mathrm{ng} / \mathrm{ml}, \mathrm{p}<0.05)$ (Fig. 2).

One month later, the concentration of MMP9 in the first group was $12.2 \pm 2.2 \mathrm{ng} / \mathrm{ml}$, which was statistically significantly different from the baseline. The same value was noted in patients of the third group. In the second and fourth group, the indices were $6.2 \pm 0.8 \mathrm{ng} / \mathrm{ml}$ and $8.7 \pm 1.1 \mathrm{ng} / \mathrm{ml}$, which was a significant decrease compared to the initial level of MMP-9 in these groups ( $p<0.05)$.

Three months later, there was a tendency to decrease MMP-9 concentration in the second and fourth groups $(5.4 \pm 2.1 \mathrm{ng} / \mathrm{ml}$ and $8.0 \pm 1.4$ $\mathrm{ng} / \mathrm{ml}$, respectively). In the first and third groups, the MMP-9 index was kept at the initial level. In the I and III groups, MMP-9 indices did not differ significantly during the entire 6-month study period (Table 3).

In the control group, the concentration of MMP-1 was $4.8 \pm 0.73 \mathrm{ng} / \mathrm{ml}$. In groups of patients with varicose veins, a significantly higher MMP-1 level was found in comparison with the control group (6.9 $\pm 1.16 \mathrm{ng} / \mathrm{ml}, \mathrm{p}<0.05)$ (Fig. 3).

A month later, all groups showed a tendency to decrease in MMP-1 concentration in comparison with the initial level $(p<0.05)$. The MMP-1 index in the first group was $5.4 \pm 0.5 \mathrm{ng} / \mathrm{ml}$, in the second $6.1 \pm 0.4 \mathrm{ng} / \mathrm{ml}$, in the third $-5.7 \pm 0.3 \mathrm{ng} / \mathrm{ml}$, in the fourth $-5.8 \pm 0.6 \mathrm{ng} / \mathrm{ml}$. Three months later, the trend towards a decrease in MMP-1 concentration in all four groups remained. Six months later, MMP-1 in all groups did not significantly differ statistically from the results that we received at the stage of patient inclusion (Table 4).

In patients with varicose veins, a higher level of TIMP-1 was observed than in the control group $(210.8 \pm 21.1 \mathrm{ng} / \mathrm{ml}$ and $154.4 \pm 14.4 \mathrm{ng} / \mathrm{ml}$, respectively, $\mathrm{p}<0.05$ ) (Fig. 4).

After one month of observation, the concentration of TIMP-1 in the first group was $216.5 \pm 12.4 \mathrm{ng} / \mathrm{ml}$, in the third $-212.3 \pm 13.2 \mathrm{ng} /$ $\mathrm{ml}$, which statistically significantly did not differ from the initial index. While in the second and fourth group the indices were $274.3 \pm 18.9 \mathrm{ng} / \mathrm{ml}$ and $280.5 \pm 14.3 \mathrm{ng} / \mathrm{ml}$, which was a significant increase in comparison with the initial level of TIMP-1 in these groups $(p<0.05)$.

Three months later, there was a tendency for an increase in the concentration of TIMP-1 in the second and fourth groups $(285.5 \pm 13.2 \mathrm{ng} / \mathrm{ml}$ and $288.1 \pm 12.9 \mathrm{ng} / \mathrm{ml}$, respectively). In the I and III 
The concentration of MMP-1 in patients of different groups $(\mathrm{M} \pm \mathrm{m})$

\begin{tabular}{lcccc}
\hline Groups & V0 & V1 (after 1 month) & V2 (after 3 months) & V3 (after 6 months) \\
& $\mathrm{ng} / \mathrm{ml}$ & $\mathrm{ng} / \mathrm{ml} / \mathrm{ml}$ & $6.3 \pm 0.9^{* *}$ \\
I. & $6.7 \pm 0.4$ & $5.4 \pm 0.5^{*}$ & $5.2 \pm 0.8^{*}$ & $7.0 \pm 0.7^{* *}$ \\
II. & $7.5 \pm 0.7$ & $6.1 \pm 0.4^{*}$ & $6.2 \pm 0.5^{*}$ & $6.2 \pm 0.4^{* *}$ \\
III. & $6.5 \pm 0.5$ & $5.7 \pm 0.3^{*}$ & $5.3 \pm 0.5^{*}$ & $6.4 \pm 0.5^{* *}$ \\
IV. & $6.9 \pm 0.4$ & $5.8 \pm 0.6^{*}$ & $5.9 \pm 0.4^{*}$ & - \\
V. & $4.8 \pm 1.3$ & - & - & - \\
\hline
\end{tabular}

Note: ${ }^{*}-$ significant difference from the initial level $(\mathrm{p}<0.05) .{ }^{* *}-$ the differences are insignificant compared to the initial level $(p>0.05) . \Delta-$ Significant difference from groups of patients with varicose veins $(p<0.05)$.

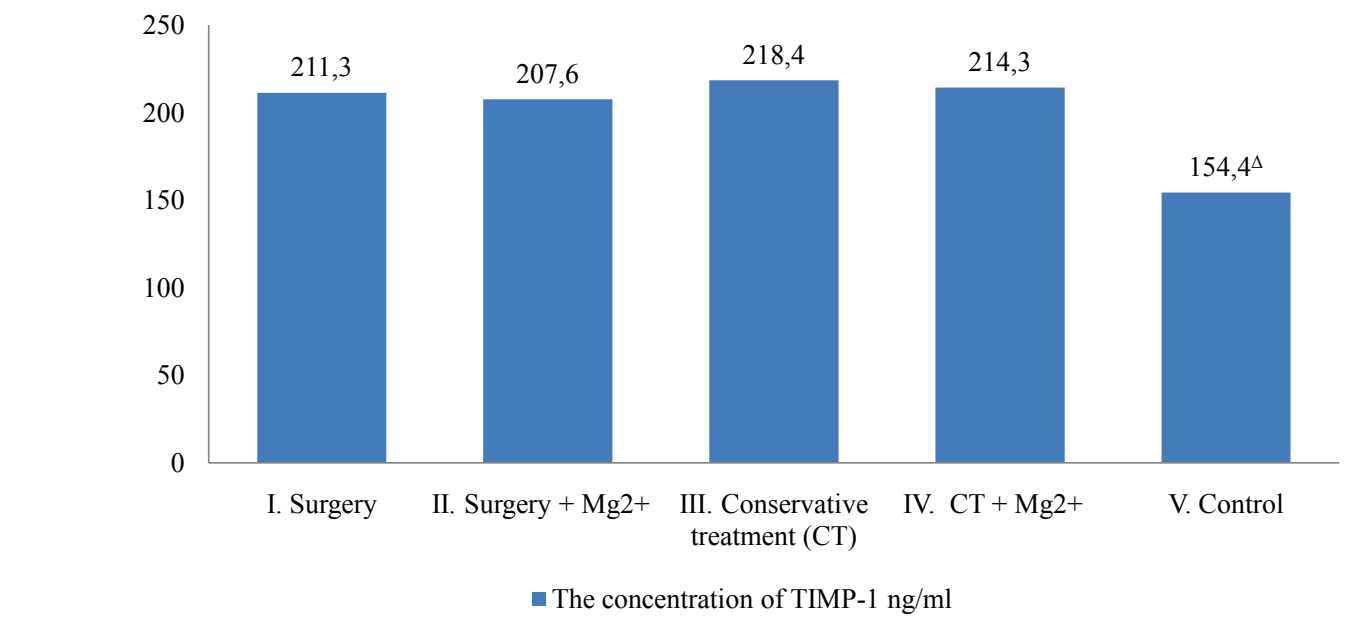

Fig. 4. The concentration of TIMP-1 in patients with varicose veins and the control group at the stage of inclusion in the study.

$\Delta-$ significant difference from groups of patients with varicose veins at the stage of screening $(p<0.05)$

groups, TIMP-1 values did not differ significantly throughout the 6-month study period (Table 5).

\section{Discussion}

For the first time, a complex biochemical evaluation of magnesium ions, matrix metalloproteinases, and tissue inhibitor of matrix metalloproteinases was carried out in patients with varicose disease of the lower limbs. The analysis of magnesium preparations effect in the treatment of this pathology was also performed.

In patients with varicose veins, a significantly lower magnesium level was observed compared to conditionally healthy volunteers who did not suffer from varicose veins (patients with a magnesium deficiency of $35.5 \%$ and $15 \%$, respectively, $p<0.05$ ), indicating the presence of connective tissue dysplasia (DCT) in patients with varicose veins.

Against the background of additional therapy with magnesium drugs (magnesium orotate), there was a decrease in the number of patients with magnesium deficiency in groups of patients with varicose veins, which created favorable prerequisites for the further course of the disease from the position of connective tissue dysplasia.

There was also a significant $(p<0.05)$ decrease in MMP-9 activity in patients of Group II and Group IV after 1 month of therapy, and it was reduced during 6 months. The concentration of TIMP-1 in these groups increased on the contrary and remained elevated against the background of magnesium

The concentration of TIMP-1 in patients of different groups $(\mathrm{M} \pm \mathrm{m})$

\begin{tabular}{|c|c|c|c|c|}
\hline Groups & $\begin{array}{c}\mathrm{V} 0 \\
\mathrm{ng} / \mathrm{ml}\end{array}$ & $\begin{array}{c}\text { V1 (after } 1 \text { month) } \\
\mathrm{ng} / \mathrm{ml}\end{array}$ & $\begin{array}{c}\text { V2 (after } 3 \text { months) } \\
n g / m l\end{array}$ & $\begin{array}{c}\text { V3 (after } 6 \text { months) } \\
\mathrm{ng} / \mathrm{ml}\end{array}$ \\
\hline I. & $211.3 \pm 11.5$ & $216.5 \pm 12.4^{* *}$ & $207.2 \pm 10.3^{* *}$ & $208.3 \pm 11.2^{* *}$ \\
\hline II. & $207.6 \pm 9.4$ & $274.3 \pm 18.9^{*}$ & $285.5 \pm 13.2^{*}$ & $291.2 \pm 11.3^{*}$ \\
\hline III. & $218.4 \pm 21.4$ & $212.3 \pm 13.2^{* * k}$ & $205.4 \pm 9.5^{* *}$ & $215.6 \pm 14.5^{* * k}$ \\
\hline IV. & $214.3 \pm 7.7$ & $280.5 \pm 14.3^{*}$ & $288.1 \pm 12.9^{*}$ & $275.2 \pm 11.9^{*}$ \\
\hline V. & $154.4 \pm 14.4$ & - & - & - \\
\hline
\end{tabular}


therapy. In the $1^{\text {st }}$ and $3^{\text {rd }}$ groups, the differences in MMP-9 and TIMP-1 concentrations were not observed during the follow-up period in comparison with the initial index. Taking into consideration the intake of magnesium drugs in the second and fourth groups of patients, one can judge about the influence of magnesium ions on the decrease of MMP-9 activity, thereby inhibiting the extracellular matrix degradation and collagen destruction processes. The most pronounced decrease was noted in the second group, where the patients were treated surgically in addition to conservative therapy.

There is a significant $(p<0.05)$ decrease in MMP-1 activity in patients with varicose veins after 1 and 3 months of the therapy. Taking into account the intake of magnesium drugs in the second and fourth groups of patients, it can be judged that magnesium ions did not affect the activity of MMP-1, and the decrease in the indices is likely due to the effect of standard therapy for patients with varicose veins.

\section{Conclusions}

One has revealed the elevated levels of MMP-1, MMP-9 and TIMP-1 in the blood and a decrease in magnesium concentration in patients with varicose veins of the lower extremities in comparison with the control group, people without varicose veins.

There is a decrease in MMP-1 concentration during varicose veins treatment during 3 months of active therapy, both in operative and in conservative treatment groups, this indicator comes to the baseline level after 6 months.

Magnesium drugs reduce the activity of MMP9 and increase the concentration of TIMP-1, thereby affecting the balance of MMP / TIMP in patients with varicose veins of the lower extremities.

\section{Funding}

The work was carried out in accordance with the Research Plan of the Ryazan State Medical University named after Acad. I.P. Pavlov. The authors did not receive any financial support from the drug manufacturers.

\section{Conflict of interest}

The authors declare that they have no conflict of interest.

\section{Ethical approval}

The study was approved by the Ethics Committee of Ryazan State Medical University named after Academician I.P. Pavlov.

\section{ЛИТЕРАТУРА}

1. Покровский АВ, Градусов ЕГ, Бредихин РА. Диагностика и лечение варикозной болезни. Москва, РФ: РМАПО; 2013. 125 с.

2. Staffa R. Chronic venous insufficiency-epidemiology. Bratisl Lek Listy. 2002;103(4-5):166-68.

3. Небылицын ЮС, Кондратьева ВИ. Опыт лечения пациентов с варикозной болезнью нижних конечностей. Наука молодых - Eruditio Juvenium. 2016;(3):52-66.

4. Кириенко АИ, Богачев ВЮ, Гаврилов СГ, Золотухин ИА, Голованова ОВ, Журавлева ОВ, Брюшков АЮ. Хронические заболевания вен нижних конечностей у работников промышленных предприятий г. Москвы. Результаты эпидемиологического исследования. Ангиология и Сосуд Хирургия. 2004;10(1):77-85.

5. Селиверстов ЕИ, Авакъянц ИП, Никишков АС, Золотухин ИА. Эпидемиология хронических заболеваний вен. Флебология. 2016;10(1):35-43. doi: 10.17116/flebo201610135-42.

6. Фомина НВ, Фомина МА. Оценка связи активности лизосомальных цистеиновых протеиназ плазмы крови и показателей эндотелиальной дисфункции у пациентов с заболеваниями вен нижних конечностей. Наука молодых - Eruditio Juvenium. 2014;(1):60-67.

7. Amălinei C, Căruntu ID, Giucă SE, Bălan RA. Matrix metalloproteinases involvement in pathologic conditions. Rom J Morphol Embryol. 2010;51(2):215-28.

8. Громова О.А. Магний и пиридоксин: основы знаний. Москва, РФ: ПротоТип; 2006. 234 с.

9. Громова ОА, Калачева АГ, Торшин ИЮ, Рудаков КВ, Грустливая УЕ, Юдина НВ, Егорова ЕЮ, Лиманова ОА, Федотова ЛЭ, Грачева ОН, Никифорова НВ, Сатарина ТЕ, Гоголева ИВ, Гришина ТР, Курамшина ДБ, Новикова ЛБ, Лисицына ЕЮ, Керимкулова НВ, Владимирова ИС, Чекмарева МН, Лялякина ЕВ, Шалаева ЛА, Талепоровская СЮ, Силинг ТБ, Прозорова НВ, Семенов ВА, Семенова ОВ, Назарова НА, Галустян АН, Сардарян ИС. Недостаточность магния достоверный фактор риска коморбидных состояний: результаты крупномасштабного скрининга магниевого статуса в регионах России. Фарматека. 2013;(6):115-29.

10. Pagès N, Gogly B, Godeau G, Igondjo-Tchen S, Maurois P, Durlach J, Bac P. Structural alterations of the vascular wall in magnesium-deficient mice. A possible role of gelatinases A (MMP-2) and B (MMP-9). Magnes Res. 2003 Mar;16(1):43-48.

\section{REFERENCES}

1. Pokrovskii AV, Gradusov EG, Bredikhin RA. Diagnostika i lechenie varikoznoi bolezni. Moscow, RF: RMAPO; 2013. 125 p. (in Russ.)

2. Staffa R. Chronic venous insufficiency-epidemiology. Bratisl Lek Listy. 2002;103(4-5):166-68.

3. Nebylitsyn IuS, Kondrat'eva VI. Experience of managing patients with primary varicosity. Nauka molodykh - Eruditio Juvenium. 2016;(3):52-66. (in Russ.)

4. Kirienko AI, Bogachev VIu, Gavrilov SG, Zolotukhin IA, Golovanova OV, Zhuravleva OV, Briushkov $\mathrm{AIu}$. Chronic diseases of lower extremity veins in industrial workers of Moscow (Results of the 
epidemiological survey). Angiologiia $i$ Sosud Khirurgiia. 2004;10(1):77-85. (in Russ.)

5. Seliverstov EI, Avak'iants IP, Nikishkov AS, Zolotukhin IA. Epidemiology of chronic venous disease. Flebologiia. 2016;10(1):35-43. doi: 10.17116/ flebo201610135-42. (in Russ.)

6. Fomina NV, Fomina MA. Assessment of communication activity of lysosomal cystein proteases in plasma and indicators of endothelial dysfunction in patients with diseases of lower limbs veins. Nauka molodykh Eruditio Juvenium. 2014;(1):60-67. (in Russ.)

7. Amălinei C, Căruntu ID, Giucă SE, Bălan RA. Matrix metalloproteinases involvement in pathologic conditions. Rom J Morphol Embryol. 2010;51(2):215-28.

8. Gromova OA. Magnii i piridoksin: osnovy znanii. Moscow, RF: ProtoTip; 2006. 234 p. (in Russ.)

9. Gromova OA, Kalacheva AG, Torshin IIu, Ruda-

\section{Адрес для корреспонденции}

390026, Российская Федерация,

г. Рязань, ул. Высоковольтная, д. 9,

Рязанский государственный медицинский

университет им. акад. И.П. Павлова,

кафедра сердечно-сосудистой,

рентгенэндоваскулярной,

оперативной хирургии и топографической анатомии, тел. +7 951 101-21-23,

e-mail: kamaev.rgmu@gmail.com,

Камаев Алексей Андреевич

\section{Сведения об авторах}

Калинин Роман Евгеньевич, д.м.н., профессор, заведующий кафедрой сердечно-сосудистой, рентгенэндоваскулярной, оперативной хирургии и топографической анатомии, Рязанский государственный медицинский университет им. акад. И.П. Павлова, г. Рязань, Российская Федерация.

http://orcid.org/0000-0002-0817-9573

Сучков Игорь Александрович, д.м.н., доцент, профессор кафедры сердечно-сосудистой, рентгенэндоваскулярной, оперативной хирургии и топографической анатомии, Рязанский государственный медицинский университет им. акад. И.П. Павлова, г. Рязань, Российская Федерация.

http://orcid.org/0000-0002-1292-5452

Пшенников Александр Сергеевич, к.м.н., доцент кафедры сердечно-сосудистой, рентгенэндоваскулярной, оперативной хирургии и топографической анатомии, Рязанский государственный медицинский университет им. акад. И.П. Павлова, г. Рязань, Российская Федерация.

http://orcid.org/0000-0002-1687-332Х

Камаев Алексей Андреевич, аспирант кафедры сердечно-сосудистой, рентгенэндоваскулярной, оперативной хирургии и топографической анатомии, Рязанский государственный медицинский университет им. акад. И.П. Павлова, г. Рязань, Российская Федерация.

http://orcid.org/0000-0002-3979-1271

Исаков Сергей Алексеевич, д.м.н., профессор кафедры дерматовенерологии, Рязанский государственный медицинский университет им. акад. И.П. Павлова, г. Рязань, Российская Федерация. kov KV, Grustlivaia UE, Iudina NV, Egorova EIu, Limanova OA, Fedotova LE, Gracheva ON, Nikiforova NV, Satarina TE, Gogoleva IV, Grishina TR, Kuramshina DB, Novikova LB, Lisitsyna EIu, Kerimkulova NV, Vladimirova IS, Chekmareva MN, Lialiakina EV, Shalaeva LA, Taleporovskaia SIu, Siling TB, Prozorova NV, Semenov VA, Semenova OV, Nazarova NA, Galustian AN, Sardarian IS. Nedostatochnost' magniia - dostovernyi faktor riska komorbidnykh sostoianii: rezul'taty krupnomasshtabnogo skrininga magnievogo statusa v regionakh Rossii. Farmateka. 2013;(6):115-29. (in Russ.)

10. Pagès N, Gogly B, Godeau G, Igondjo-Tchen S, Maurois P, Durlach J, Bac P. Structural alterations of the vascular wall in magnesium-deficient mice. A possible role of gelatinases A (MMP-2) and B (MMP-9). Magnes Res. 2003 Mar;16(1):43-48.

\section{Address for correspondence}

390026, The Russian Federation,

Ryazan, Vyisokovoltnaya str., 9,

Ryazan State Medical University

named after Academician I.P. Pavlov,

Department of Cardiovascular,

$\mathrm{X}$-Ray Endovascular,

Operative Surgery and Topographic Anatomy,

Tel. 7951 101-21-23,

e-mail: kamaev.rgmu@gmail.com,

Kamaev Aleksey Andreevich

\section{Information about the authors}

Kalinin Roman E., MD, Professor, Head of the Department of Cardiovascular, X-Ray Endovascular, Operative Surgery and Topographic Anatomy of Ryazan State Medical University named after Academician I.P. Pavlov, Ryazan, Russian Federation.

http://orcid.org/0000-0002-0817-9573

Suchkov Igor A., MD, Associate Professor, Professor of the Department of Cardiovascular, X-Ray Endovascular, Operative Surgery and Topographic Anatomy of Ryazan State Medical University named after Academician I.P. Pavlov, Ryazan, Russian Federation.

http://orcid.org/0000-0002-1292-5452

Pshennikov Alexander S., PhD, Associate Professor of the Department of Cardiovascular, X-Ray Endovascular, Operative Surgery and Topographic Anatomy of Ryazan State Medical University named after Academician I.P. Pavlov, Ryazan, Russian Federation.

http://orcid.org/0000-0002-1687-332X

Kamaev Aleksey A., Post-Graduate Student of the Department of Cardiovascular, X-Ray Endovascular, Operative Surgery and Topographic Anatomy of Ryazan State Medical University named after Academician I.P. Pavlov, Ryazan, Russian Federation.

http://orcid.org/0000-0002-3979-1271

Isakov Sergey A., MD, Professor of the Dermatovenereology Department of Ryazan State Medical University named after Academician I.P. Pavlov, Ryazan, Russian Federation.

http://orcid.org/0000-0002-0694-1309

Ryabkov Alexander N., MD, Associate Professor of the Department of Pharmacology with the Course of Pharmacy of the Faculty of Additional Professional Edu- 
http://orcid.org/0000-0002-0694-1309

Рябков Александр Николаевич, д.м.н., доцент кафедры фармакологии с курсом фармации ФДПО, Рязанский государственный медицинский университет им. акад. И.П. Павлова, г. Рязань, Российская Федерация.

http://orcid.org/0000-0003-4705-747X

\section{Информация о статье}

Поступила 7 марта 2017 г.

Принята в печать 26 июня 2017 г. Доступна на сайте 5 февраля 2018 г. cation of Ryazan State Medical University named after Academician I.P. Pavlov, Ryazan, Russian Federation. http://orcid.org/0000-0003-4705-747X

\section{Article history}

Arrived 7 March 2017

Accepted for publication 26 June 2017

Available online 5 February 2018 